\section{Determinants of employees' psychological ownership on budgetary slack}

Cheok Mui YEE, Edward Wong Sek KHIN, E-mail: edwardwong@um.edu.my

Kamisah ISMAIL, Faculty of Business and Accountancy, University of Malaya, Malaysia

\section{Alustract}

The existence of budgetary slack permeates every level of private sector organisations. Employees (i.e., budget makers) usually request excessive budgetary resources in the budgeting process. Due to its dysfunctional nature, existing researchers had extensively examined the relationship between budgetary slack and employees' performance. This study adopted a survey questionnaire approach to examine the relationship between determinants of psychological ownership and employees' intention to create slack in budgeting. There were 475 budget makers from private sector organisations in the Klang Valley, Malaysia who participated in this study through a questionnaire survey. Preliminary data analysis was performed using normality, multi-collinearity, variance inflation index (VIF), common method variance, and reliability analysis. Multiple regression analysis was also applied to investigate the relationships of each dimension of employees' psychological ownership on budgetary slack. This paper is considered a pioneer empirical study that investigates the determinants of psychological ownership on budgetary slack among budget makers from the psychological perspective in the context of private sector organisations in Malaysia, where slack activities in budgeting existed.

Keywords: Budgetary slack, psychological ownership, private sector organisations

JEL Classification: C11, D32, M47, 052.

\section{To cite this article:}

Yee, C.M., Khin, E.W.S. and Ismail, K. (2018), Determinants of employees' psychological ownership on budgetary slack, Audit Financiar, vol. XVI, no. 1(149)/2018, pp. 122-130,

DOI: 10.20869/AUDITF/2018/149/004

To link to this article:

http://dx.doi.org/10.20869/AUDITF/2018/149/004

Received: 14.06 .2017

Revised: 29.07.2017

Accepted: 13.08.2017 


\section{Introduction}

Private sector organisations accumulate slack resources as a form of contingency plans, regardless the nature of companies. They utilise these resources to cope with unpredictable environmental influences such as economic uncertainty and internal financial issues. In other words, slack building is particularly important in balancing budget estimates at the end of each year. Otherwise, they have little room to adjust their budget structure to meet unforeseen contingency needs (Williams, Macintosh and Moore, 1990). These adjustments usually come with an enormous potential economic and non-economic cost especially when companies are struggling to seek a beneficial public welfare or profitability opportunities (Murwaningsari, 2008).

Budget slack triggers socio-economic pressures from stakeholders as private sector organisations companies are pressured to allocate adequate resources for potential investment opportunities while aggressively pushing for public welfare satisfaction. Such pressures trigger bias in building additional resources for contingencies (Mohamed Yunos et al., 2012).

Private sector organisations usually accumulate budgetary slack resources in several ways. Firstly, employees set a budget estimate whereby expenditure is lower than the anticipated revenue. However, this form of slack building is highly attention grabbing to stakeholders, although it is more accessible by employees in the private sector organisations (Yilmaz, Ozer and Gunluk, 2014). Alternatively, they balance the budget estimate by purposefully underestimating revenues or overestimating expenditure. Lastly, they pre-allocate funds for contingency purposes. The last two forms of slack building are less discretionary to internal parties and less transparent in the eyes of stakeholders.

\section{Literature review}

\subsection{Budgetary slack}

Employees are expected to be self-interest-centred when they are incentive-driven and when they have opportunity to do so without superiors' knowledge (Lukka, 1988). In turn, they will have intentions to act against the company's goals. That is the main reason that their performance evaluation is tied with the attainability of company's budgetary goals (Lau and Buckland, 2001). As a result, employees are often concerned with their performance level as they are expected to exceed the budgetary goals that are predetermined by their superiors, although they negotiated the budgeted target. In other words, employees have the tendency to withhold their valuable resources even though the organizations encourage their active participation in the budget planning process. They are biased towards the building of additional resources and under-perform in achieving targeted productivity level, which is referred to as budgetary slack (Kuvaas, 2003). Budgetary slack is usually regarded as dysfunctional as it contradicts with a company's interests, regardless of being for a profitable opportunity or for the public welfare. The slack activities are undetectable, as it may happen in all stages of the budgeting process, particularly when employees purposefully act without the knowledge of the company. Although the top management is authorised to accept or reject employees' budget proposals, it is unable to verify the information provided in the proposed budget in spite of the post-mortem budget meeting, as the management team may still be unable to trace the possibility of slack activities as they take into account possible internal and external factors such as error in budget forecasting and environmental uncertainty (Hammer and Stern, 1980).

\subsection{Employees' psychological ownership}

Employees produce positive or negative or mixed behavioural outcomes through psychologically experienced ownership (Pierce, Kostova and Dirks, 2001). They become emotionally attached to tangible and intangible possessions surrounding them as though they are personally owned. Eventually, they portray such acts of possession in their minds and actions. They become motivated to cultivate a strong feeling of protection towards their possessions, either personal or impersonal. They seek physical and emotional control over this form of possession.

\section{Dimensions of employee's psychological ownership}

Building on psychological ownership theory, Pierce, Kostova and Dirks (2001) and Avey et al. (2009) recognised five dimensions of employees' psychological ownership in organisational context. Employees' feeling over psychological ownership draws upon the concepts of self-efficacy, belongingness, self-identity, accountability and territoriality. 


\section{Belongingness}

Belongingness refers to employees' desire of dwelling into a place, i.e., organisations. It is a fundamental need of employees, as it emphasises on their psychological state of belonging with others. Employees take ownership of possession around them in an effort to fulfil their desire of belonging (Ardrey, 1966). Employees tend to retain possession, such as name cards, as a form of tangible security objects to provide them with a sense of belongingness. Such feeling of psychological ownership through the attachment of objects, tangible or intangible, becomes a place for employees (Pierce, Kostova and Dirks, 2001).

\section{Self-identity}

Self-identity is recognised as a major component of the self-concept domain, along with social identity. Employees identity themselves through the groups of people and possessions (Abrams and Hogg, 2004). They create, sustain, replicate and change their self-identity through interaction with these people and tangible possessions (Dittmar, 1992) and even intangible possessions, such as organisations (Rousseau, 1998). For instance, employees may define themselves as a house or even a job title. Such targets of ownership are regularly used as descriptors of their identity. The feeling of psychological state of ownership over people, tangible and intangible objects provide a foundation from which employees identify themselves as being distinctive and therefore contributing to their personal identity.

\section{Accountability}

Accountability refers to "the implicit or explicit expectation that one may be called on to justify one's belief, feelings and actions to others" (Lerner and Tetlock, 1999, p. 255). Employees take ownership psychologically through two approaches: (1) their expected right to hold others accountable and (2) the expectation of holding themselves accountable. For instance, employers hold their employees accountable for organisational performance. At the same time, employers themselves are held accountable by investors or stakeholders. Such description of expected rights and responsibilities is described as a form of behaviour that characterise stewardship and self-sacrifice towards the protection of the target of ownership.

\section{Territoriality}

Employees tend to become territorial over tangible or intangible objects, such as ideas, roles and relationships as their target of ownership. This is considered as a selfserving act that places great importance for satisfying needs, either personal or organisational interest. When employees establish ownership bonding with the target of possessions, they may mark these possessions as their exclusive belonging. If they anticipate encroachment on their target of possessions, they may prompt to protective territoriality to demonstrate ownership rights.

\section{Hynotheses}

\section{Self-efficacy and budgetary slack}

When employees perform their tasks and responsibilities, they develop a sense of control towards the target of possessions, i.e., budget. They perceive that they are able to control the building of excessive budgetary resources. At the same time, they become efficient in their budgeting skills and therefore control the excessive budgetary resources. It implies that employees are provided with selfefficacy which enables them to control their intention to create budgetary slack. Thus, it is hypothesised that:

\section{H1: There is a negative relationship between self- efficacy and employees' intention to create budgetary slack.}

\section{Belongingness and budgetary slack}

Employees develop their sense of attachment through the possession of budgets, although it is intangible in nature. Such target of ownership, however, offers employees the feeling of security towards their tasks and responsibilities. They then perceive that they are able to control the building of excessive budgetary resources. When employees desire to attach themselves with budgets, they consider budgets as their personal belonging and therefore they need to control the excessive budgetary resources. It implies that employees are provided with the sense of belongingness that enables them to control their intention to create budgetary slack. Hence, it is hypothesised that:

H2: There is a negative relationship between belongingness and employees' intention to create budgetary slack.

\section{Self-identity and budgetary slack}

Employees identify themselves with the possession of budgets in the organisations. They replicate and change 
their identity through their budgetary tasks and responsibilities in spite of its intangibility. The possession of budget becomes a self-identity to them in the organisations. They even use such identity to distinguish themselves with others. While employees create an identity of themselves with the possession of budgets, they extend their social self towards such possession. In turn, they may tend to control their actions towards the building of excessive budgetary resources. It implies that the employees are provided with self-identity, which enables them to control their intention to create budgetary slack. Thus, it is hypothesised that:

H3: There is a negative relationship between self-identity and employees' intention to create budgetary slack.

\section{Accountability and budgetary slack}

Employees hold themselves accountable for the budgetary task and responsibilities. They tend to justify their actions while meeting the expectation of organisations. They perceive that they have the responsibilities to achieve organisational, including budgetary targets when performing budgeting estimate. Such promotive behaviour encourages employees to control the building of excessive budgetary resources. It implies that when employees feel that they are accountable for their budgetary actions, they may control their intention to create budgetary slack. Thus, it is hypothesised that:

H4: There is a negative relationship between accountability and employees' intention to create budgetary slack.

\section{Territoriality and budgetary slack}

Employees become territorial over budgetary tasks and responsibilities, as they consider budgeting as their target of ownership. They tend to place great importance in protecting their tasks and responsibilities to sustain the positive side of the possession. When employees establish and sustain the bonding with budgetary tasks and responsibilities, they perceive that they are able to claim exclusive right to such possession. They may then prompt to control the building of excessive budgetary resource. It implies that employees are provided with the territoriality feature which enables them to control their intention to create budgetary slack. Thus, it is hypothesised that:

H5: There is a negative relationship between territoriality and employees' intention to create budgetary slack.

Based on the proposed hypotheses above, the conceptual framework of the model is illustrated in Figure no. 1.

\section{Figure no. 1: Conceptual model}

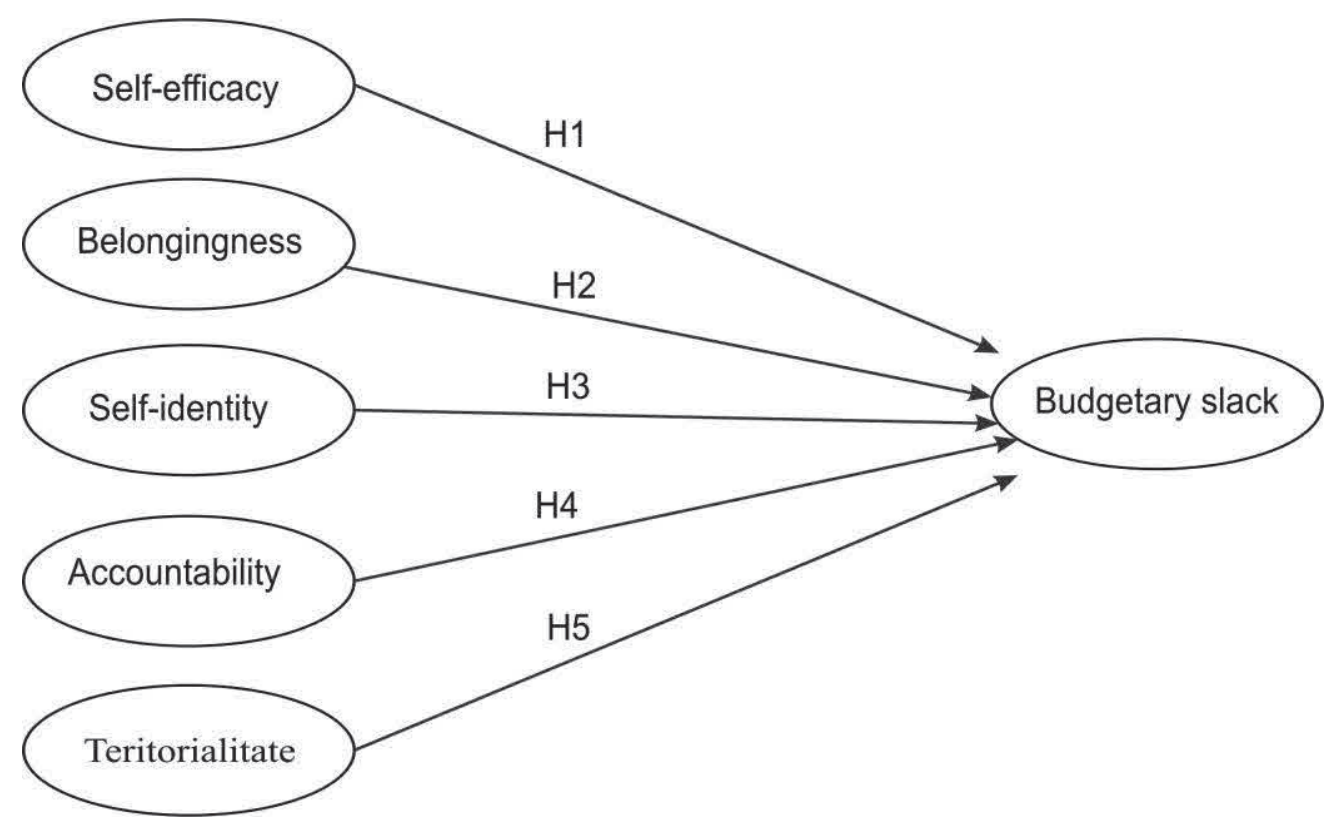

No. 1(149)/2018 


\section{Research method}

\section{Participants}

The population of respondents in this study were employees who held lower or higher job designations, who worked in private organisations, with prior experience in budgeting or were involved in the budgeting actively. Sampling techniques such as snowball and quota sampling were used to gain a generalised view on employees' perceptions pertaining to budgetary slack and psychological ownership because these approaches secured positive a response rate of returned questionnaires to perform adequate and relevant statistical analysis. The qualifications of these potential respondents were verified to determine whether they fitted the sample description before receiving the questionnaire.

\section{Budgetary slack measurement}

Propensity to slack measures the extent to which the amount budgeted is likely to be purposefully manipulated with the lack of monitoring activity performed on the task assignment. There were eight composited items, which were measured with seen-point semantic differential scale. An example of propensity to create budgetary slack was 'I seek more budgetary resources than absolutely necessary when preparing a budget.

\section{Psychological ownership measurement}

The dimension of psychological ownership was measured using six-point Likert scale developed by Avey et al. (2009).

\section{Self-efficacy}

Self-efficacy was operationalised as employees who have the ability to control the possessions. It consisted of three items and a sample question for self-efficacy is 'I feel I need to protect my ideas from being used by others in my organisation'.

\section{Belongingness}

Belongingness was operationalised as employees who attach their feelings of possessions as their personal belonging. It has three items and a sample question is 'I feel I belong in this organisation.

\section{Self-identity}

Self-identity was operationalised as employees who identify their personal identity with the possessions. It consists of three items and a sample question for self-identity is 'I am confident in my ability to contribute to my budgetary task's success.

\section{Accountability}

Accountability was operationalised as employees who justify their actions towards the possessions. It has three items and a sample question is 'I would challenge anyone in my organisations if I thought the budget was done wrongly.

\section{Territoriality}

Territoriality was operationalised as employees who are territorial towards the possessions. It consists of four items and a sample question for territoriality is 'I feel I need to protect my budgetary idea from being used by others in my organisation.

\section{Results}

\section{Respondents' profile}

Out of 475 respondents, there were 384 females $(81 \%)$ and 91 males (19\%). Besides, a total of 363 respondents (76\%) were aged between 31 and 40 years old and followed by 97 respondents (20\%) were aged between 21 and 30 years old. There were 279 respondents (59\%) who earned between RM4,001 and RM5,000 and followed by 68 respondents (14\%) who earned between RM3,001 and 4,000 monthly. There were 281 (59\%) respondents who were managerial employees as compared to 194 non-managerial employees (41\%). A total of 238 respondents (50\%) were employed by their organizations for between 11 and 15 years and followed by 156 respondents (33\%) who had work experience of between 6 and 10 years. The descriptive analysis of respondents is illustrated in Table no. 1. 


\begin{tabular}{|c|c|c|c|}
\hline Item & Description & $f$ & $\%$ \\
\hline \multirow[t]{3}{*}{ Gender } & Male & 91 & 19 \\
\hline & Female & 384 & 81 \\
\hline & Total & 475 & 100 \\
\hline \multirow[t]{6}{*}{ Age } & Below 21 years old & 0 & 0 \\
\hline & Between 21 and 30 years old & 97 & 20 \\
\hline & Between 31 and 40 years old & 363 & 76 \\
\hline & Between 41 and 50 years old & 14 & 3 \\
\hline & Above 50 years old & 1 & 0 \\
\hline & Total & 475 & 100 \\
\hline \multirow[t]{7}{*}{ Monthly income } & $\mathrm{RM} 2,000$ or below & 0 & 0 \\
\hline & Between RM 2,001 and RM3,000 & 30 & 6 \\
\hline & Between RM3,001 and RM4,000 & 68 & 14 \\
\hline & Between RM4,001 and RM5,000 & 279 & 59 \\
\hline & Between RM5,001 and RM6,000 & 31 & 7 \\
\hline & Above RM6,000 & 67 & 14 \\
\hline & Total & 475 & 100 \\
\hline \multirow[t]{4}{*}{ Current job position } & Non-managerial level & 194 & 41 \\
\hline & Managerial level & 281 & 59 \\
\hline & Others & 0 & 0 \\
\hline & Total & 475 & 100 \\
\hline \multirow{7}{*}{$\begin{array}{l}\text { Numbers of years working in the current } \\
\text { organisation }\end{array}$} & Less than 1year & 0 & 0 \\
\hline & Between 1 and 5 years & 63 & 13 \\
\hline & Between 6 and 10 years & 156 & 33 \\
\hline & Between 11 and 15 years & 238 & 50 \\
\hline & Between 16 and 20 years & 17 & 4 \\
\hline & More than 20 years & 1 & 0 \\
\hline & Total & 475 & 100 \\
\hline
\end{tabular}

\section{The result of social desirability response (SDR)}

Recognising the existence of possible bias in the social desirability response (SDR), all variables studied were adjusted using the approach recommended by
Anderson, Warner and Spencer (1984, p. 576). The statistical analysis of the sample data using the adjusted measure suggested that SDR bias influenced the proposed relations among the factors in the model (refer to Table no. 2).

\section{Table no. 2: The result from social desirability response (SDR)}

\begin{tabular}{|l|c|c|c|}
\multicolumn{1}{|c|}{ Variable } & $\mathrm{t}$ value & $\mathrm{p}$ value & Evidence of SDR \\
\hline Budgetary slack & 1.27 & 0.02 & Yes \\
\hline Self-efficacy & 1.78 & 0.01 & Yes \\
\hline Belongingness & 1.54 & 0.01 & Yes \\
\hline Self-identity & 1.62 & 0.03 & Yes \\
\hline Territoriality & 1.31 & 0.03 & Yes \\
\hline Accountability & 1.82 & 0.00 & Yes \\
\hline
\end{tabular}




\section{Preliminary data analysis}

The data in this study was assumed normally distributed (refer to Table no. 4). Besides, the critical $X^{2}$ value for $d f$ $=4$ at $\alpha=.05$ is 9.49 for any of the cases in the data file (Malhotra, 2010). As the Mahalanobis distance was only 3.56 , it indicated that there was no presence of multivariate outlier.
In addition to that, the first factor in the study only accounted for $23.5 \%$ of the overall variance when the principal axis factoring with rotation was applied. It indicated that there was no one factor accounted for a majority of the variance. It implied that the result was unlikely affected by common method variance and concluded that multicollinearity was not a concern.

\section{Table no. 4: Mean, standard deviation, skewness \& kurtosis}

\begin{tabular}{|l|c|c|c|c|}
\hline \multicolumn{1}{|c|}{ Variable } & M & SD & Skewness & Kurtosis \\
\hline Budgetary slack & 3.33 & 0.91 & 0.12 & -0.19 \\
\hline Self-efficacy & 3.94 & 1.22 & -0.23 & -0.72 \\
\hline Belongingness & 3.56 & 1.11 & 0.02 & -0.51 \\
\hline Self-identity & 3.68 & 1.11 & 0.02 & -0.51 \\
\hline Territoriality & 3.64 & 0.92 & -0.22 & 0.12 \\
\hline Accountability & 3.48 & 1.11 & 0.08 & -0.50 \\
\hline
\end{tabular}

\section{Reliability and validity}

In terms of reliability, all the reflective constructs, such as self-efficacy, belongingness, self-identity, accountability and territoriality, were demonstrated with satisfactory score in internal consistency of 0.70 or above (Nunnally \& Bernstein, 1994; Nunnally, 1978, p. 245) (refer to Table no. 4). Besides, since budgetary slack was a formative construct, its Tukey's test of non-additivity showed that it was additive $(F=1.73, d f=1.24, p=.19)$.

\section{Table no. 4: Reliability}

\begin{tabular}{|l|c|}
\multicolumn{1}{c|}{ Variable } & $\alpha$ \\
\hline Self-efficacy & 0.88 \\
\hline Belongingness & 0.83 \\
\hline Self-identity & 0.84 \\
\hline Territoriality & 0.78 \\
\hline Accountability & 0.78 \\
\hline
\end{tabular}

\section{Hypotheses results}

The overall model was significant $(F-v a l u e=26.45$, $p<0.05$ ) and therefore it is fit. The model also explained $22 \%$ of the variation in employees' intention to create budgetary slack. Besides, there was no multi-collinearity issue in the model as its variance inflation factor (VIF) value was less than 5 (refer to Table no. 5).

Based on the empirical model in Figure no. 2, selfefficacy was negatively related to employees' intention to create budgetary slack ( $\mathrm{t}$ value $=-3.35, p<0.05$ ). Belongingness was also negatively significant with employees' intention to create budgetary slack ( $\mathrm{t}$ value $=$
$-2.30, p<0.05)$. Besides, self-identity was negatively related to employees' intention to create budgetary slack $(\mathrm{t}$-value $=-3 / 01, p<0.05)($ refer to Table no. 5).

Self-efficacy $(\beta=-3.35)$ was the most important determinant that influenced employee's intention to create budgetary slack, among belongingness $(\beta=0.30)$ and self-identity $(\beta=0.30)$.

However, accountability was not significantly related to employees' intention to create budgetary slack ( $\mathrm{t}$ value $=$ $-0.77, p>0.05$ ). Territoriality was also not significantly related to employees' intention to create budgetary slack ( t value $=-1.80, p<0.05)($ refer to Table no. 5$)$. 


\section{Table no. 5: Model evaluation}

\begin{tabular}{|c|c|c|c|}
\hline Variable & $\beta$ & $t$ value & $p$-value \\
\hline Territoriality & -0.07 & -1.70 & 0.09 \\
\hline Self-efficacy & -0.18 & -3.35 & $0.00^{* *}$ \\
\hline Accountability & -0.04 & -0.77 & 0.45 \\
\hline Belongingness & -0.13 & -0.30 & $0.02^{* *}$ \\
\hline Self-identity & -0.18 & -0.30 & $0.00^{* *}$ \\
\hline Adjusted $\mathbf{R}^{2}$ & & 0.22 & \\
\hline F value & & 26.45 & \\
\hline Sig. & & $0.00^{* *}$ & \\
\hline
\end{tabular}

\section{Empirical model}

The empirical model for the relationship between

employees' psychological ownership dimensions and budgetary slack was presented in Figure no. 2.

\section{Figure no. 2: Empirical model}

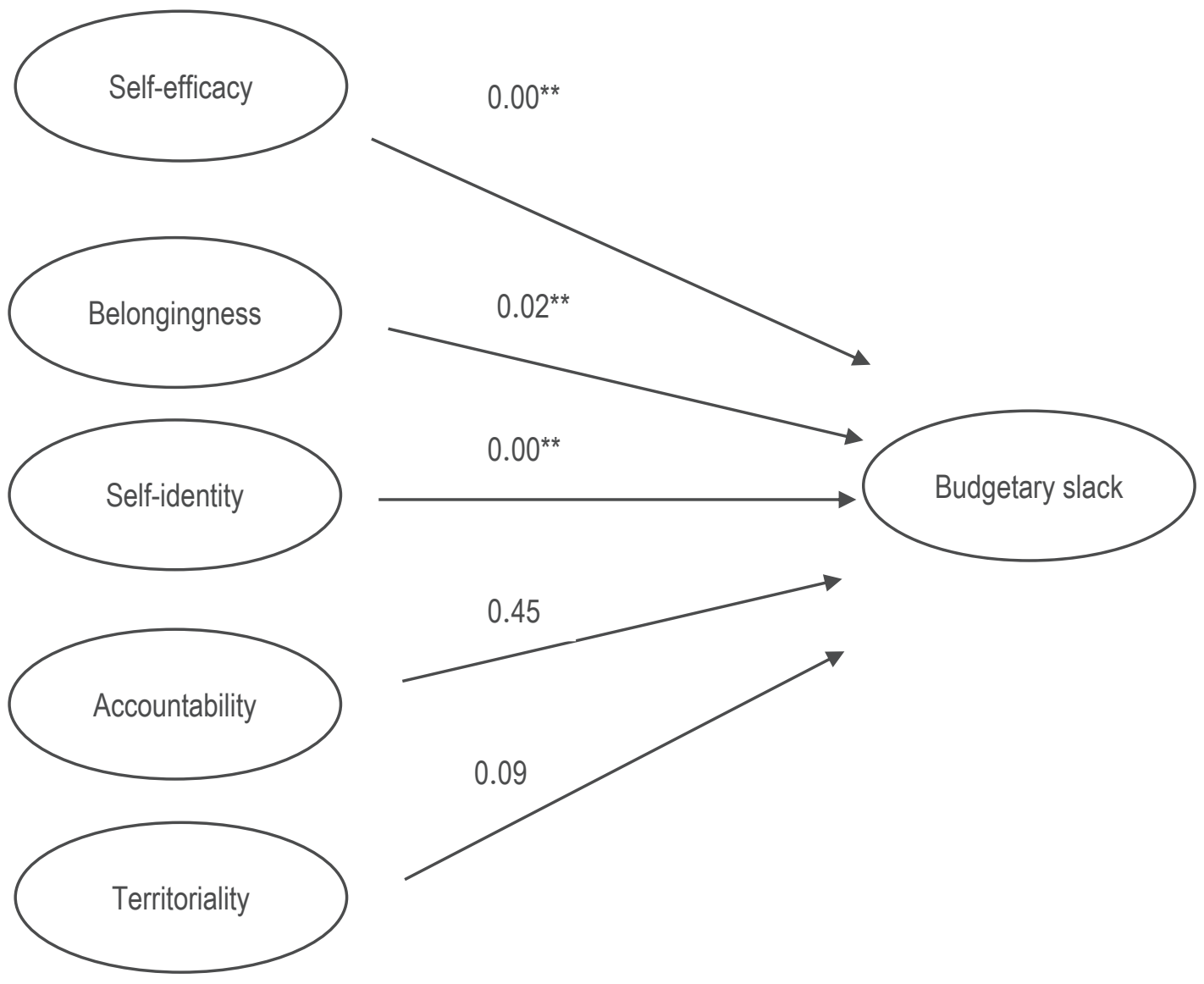

No. $1(149) / 2018$ 


\section{Ponclusion}

This paper investigates the determinants of employees' psychological ownership from the psychological perspective. It has concluded that budget makers who were self- efficient, in addition to belongingness and selfidentity, may minimise or even avoid the creation of slack resources in budgeting. They may be encouraged to become the persons to manage the distribution of budgetary resources in organisations. To a certain extent, managing employees' ownership towards the possession of budgetary resources may effectively minimise or even avoid the creation of budgetary slack.

\section{REFERENCES}

1. Abrams, D. and Hogg, M.A. (2004), Metatheory: Lessons from social identity research, Personality and Social Psychology Review, vol. 8, no. 2, pp. 98106, DOI 10.1207/s15327957pspr0802_2.

2. Anderson, C.D., Warner, J.L. and Spencer, C.C. (1984), Inflation bias in self-assessment examinations: Implications for valid employee selection, Journal of Applied Psychology, vol. 69, no. 4, 574-580, DOI 10.1037/0021-9010.69.4.574.

3. Ardrey, R. (1966), The territorial imperative: A personal inquiry into the animal origins of property and nations, Oxford, England.

4. Avey, J.B., Avolio, B.J., Crossley, C.D. and Luthans, F. (2009), Psychological ownership: Theoretical extensions, measurement and relation to work outcomes, Journal of Organizational Behavior, vol. 30, no. 2, pp. 173-191, DOI 10.1002/job.583.

5. Dittmar, H. (1992), The Social Psychology of Material Possessions: To have is to be, New York: St Martin's Press.

6. Hammer, T.H. and Stern, R.N. (1980), Employee ownership: Implications for the organizational distribution of power, Academy of Management Journal, vol. 23 , no. 1, pp. 78-100, DOI $10.2307 / 255497$.

7. Kuvaas, B. (2003), Employee ownership and affective organizational commitment: Employees' perceptions of fairness and their preference for company shares over cash, Scandinavian Journal of Management, vol. 19, no. 2, pp. 193-212, DOI 10.1016/s0956-5221(01)00044-6.

8. Lau, C.M. and Buckland, C. (2001), Budgeting - the role of trust and participation: A research note, Abacus, vol. 37, no. 3, pp. 369-388, DOI 10.1111/1467-6281.00092.

9. Lerner, J.S. and Tetlock, P.E. (1999), Accounting for the effects of accountability, Psychological bulletin, vol. 125 , no. 2, pp. 255-275, DOI 10.1037//00332909.125.2.255.
10. Lukka, K. (1988), Budgetary biasing in organizations: Theoretical framework and empirical evidence, Accounting, Organizations and Society, vol. 13, no. 3, pp. 281-301, DOI 10.1016/03613682(88)90005-0.

11. Mohamed Yunos, R., Ismail, Zubaidah and Smith, M. (2012), Ethnicity and accounting conservatism: Malaysian evidence, Asian Review of Accounting, vol. 20, no. 1, pp. 34-57, DOI 10.1108/13217341211224718.

12. Murwaningsari, E. (2008), The role of organizational commitment and procedural justice in moderating the relationship between budgetary participation and managerial performance, Gadjah Mada International Journal of Business, vol. 10, no. 2, pp. 185-210.

13. Rousseau, D.M. (1998), Why workers still identify with organizations, Journal of Organizational Behavior, vol. 19, no. 3, pp. 217-233, DOI 10.1002/(sici)1099-1379(199805)19:3<217::aidjob931>3.3.co;2-e.

14. Pierce, J.L., Kostova, T. and Dirks, K.T. (2001), Toward a theory of psychological ownership in organizations, Academy of Management Review, vol. 6, no. 2, pp. 298-310, DOI 10.5465/amr.2001.4378028.

15. Williams, J.J., Macintosh, N.B. and Moore, J.C. (1990), Budget-related behavior in public sector organizations: Some empirical evidence, Accounting, Organizations and Society, vol. 15, no. 3, pp. 221-246, DOI 10.1016/03613682(90)90006-g.

16. Yilmaz, E., Ozer, G. and Gunluk, M. (2014), Do organizational politics and organizational commitment affect budgetary slack creation in public organizations?, Procedia - Social and Behavioral Sciences, vol. 150, pp. 241-250, DOI 10.1016/j.sbspro.2014.09.047. 